\title{
Low-Density Lipoprotein Cholesterol Levels and Disease Severity in COVID-19 Pneumonia
}

\section{COVID-19 Pnömonisinde Düşük Yoğunluklu Lipoprotein Kolesterol Düzeyleri ve Hastalık Şiddeti İlişkisi}

\author{
Müge Bilge1, (1) Işıl Kibar Akıllı² \\ ${ }^{1}$ University of Health Sciences Turkey, Bakirköy Dr. Sadi Konuk Training and Research Hospital, Clinic of Internal Medicine, İstanbul, Turkey \\ 2University of Health Sciences Turkey, Bakirköy Dr. Sadi Konuk Training and Research Hospital, Clinic of Pulmonary Disease, İstanbul, Turkey
}

\begin{abstract}
Objective: Pneumonia and acute respiratory distress syndrome are observed as major complications in Coronavirus disease-2019 (COVID-19). Cholesterol is a principal lipid component of the cell membranes. Lipoproteins have a fundamental role as the first line of defense against microbes. Lipoprotein levels are altered during viral infections. This study aimed to investigate the association between low-density lipoprotein cholesterol (LDL-C) levels and disease severity of patients hospitalized with COVID-19 pneumonia.

Methods: This is a retrospective and observational study of 817 patients with Severe Acute Respiratory syndrome-Coronavirus-2 (SARS-CoV-2), who are diagnosed with COVID-19 using the real-time polymerase chain reaction and are hospitalized due to moderate and severe COVID-19 pneumonia.

Results: Among 817 patients with COVID-19 pneumonia, 347 (42.5\%) were moderate and 470 (57.5\%) were severe. Total cholesterol (TC) and $\mathrm{LDL}-\mathrm{C}$ levels reduced in patients who have severe condition than those with moderate condition ( $p=0.02, p=0.03$, respectively). TC and LDL-C were negatively correlated with the hospitalization duration $(r=-0.163, p=0.02, r=-0.154, p=0.03$, respectively).

Conclusion: Our results suggest a decreased LDL-C levels in patients with COVID-19 in relation to disease severity. Therefore, a strong link was found between lipid metabolism and SARS-CoV-2, which allow us to suggest LDL as a marker indicating COVID-19 severity in the near future.
\end{abstract}

Keywords: COVID-19 pneumonia, low-density lipoprotein cholesterol, disease severity

\section{öz}

Amaç: Pnömoni ve akut solunum sıkıntısı sendromu, Koronavirüs hastalığı-2019 (COVID-19) majör komplikasyonlar olarak karşımıza çıkmaktadır. Kolesterol, hücre zarlarının başlıca lipid bileşenidir. Lipoproteinlerin mikroplara karşı ilk savunma hattı olarak temel bir role sahip olduğu bilinmektedir. Viral enfeksiyonlar sırasında lipoprotein seviyeleri değişir. Bu çalışmada, COVID-19 pnömonisi ile hastaneye yatıılan hastaların düşük yoğunluklu lipoprotein kolesterol (LDL-C) seviyeleri ile hastalık şiddeti arasındaki ilişkiyi araştırdık.

Gereç ve Yöntem: Polimeraz zincirleme reaksiyonu testi ile COVID-19 tanısı konan ve orta ve şiddetli COVID-19 pnömonisi nedeniyle hastaneye yatırılan Şiddetli Akut Solunum sendromu-Koronavirüs-2 (SARS-CoV-2) 817 hastanın retrospektif ve gözlemsel bir çalışmasıdır.

Bulgular: COVID-19 pnömonisi olan 817 hastanın 347'si $(\% 42,5)$ orta, 470'i $(\% 57,5)$ şiddetli klinik tabloda idi. Ağır hastalarda toplam kolesterol (TC) ve LDL düzeyleri orta şiddette hastalarla karşılaştııılığında anlamlı olarak daha düşüktü (sırasıyla $p=0,02, p=0,03$ ). TC ve LDL-K ile hastanede yatış süresi arasında negatif korelasyon saptandı (sırasıyla $r=-0,163, p=0,02, r=-0,154, p=0,03$ ).

Sonuç: Sonuçlarımız hastalığın ciddiyeti ile ilişkili olarak COVID-19 hastalarında LDL-C düzeylerinde azalma olduğunu göstermektedir. Lipid metabolizması ile SARS-CoV-2 arasında yakın gelecekte LDL-C COVID-19'un şiddetini gösteren bir belirteç olarak önermemize izin verebilecek güçlü bir bağlantı olduğu sonucuna varılmıştır.

Anahtar Kelimeler: COVID-19 pnömonisi, düşük yoğunluklu lipoprotein kolesterol, hastalık şiddeti

Address for Correspondence: Müge Bilge, University of Health Sciences Turkey, Bakirköy Dr. Sadi Konuk Training and Research Hospital, Clinic of Internal Medicine, İstanbul, Turkey

Phone: +90 5337335467 E-mail: mugebilge@yahoo.com ORCID ID: orcid.org/0000-0001-7965-3407 


\section{INTRODUCTION}

Severe Acute Respiratory syndrome-Coronavirus-2 (SARSCoV-2), possibly leading to poor outcomes, is known as a single origin of coronavirus disease-19 (COVID-19) pandemic. Pneumonia, acute respiratory distress syndrome, and septic shock are observed as major complications of the disease, leading to death.

Previously, SARS-CoV-1 caused "SARS," in 2002 (1). Thereafter, the "middle east respiratory syndrome coronavirus (MERS-CoV)" caused the second outbreak in the past two decades (2).

Some common features were found among SARS-CoV-1, MERS-CoV, and SARS-CoV-2 from the epidemiological, clinical, molecular, and infectious aspects (3).

The onset of infections starts with a viral entrance to the host cell. Coated viruses, including CoVs, initially activate the plasma membrane fusion or endocytosis processes for the entrance. SARS-CoV-2, similar to SARS-CoV-1, employs human angiotensin converting enzyme 2 (ACE2) as a receptor to successfully enter the cell (4). ACE2 molecules located in the lipid rafts are widely available in alveolar type Il epithelial cells (5).

Studies confirmed that the lipoproteins served as the initial defense barrier against the invading microbes (6), whose levels change during viral infections (7). Cholesterol known as a major lipid in the cell membrane is also an important component within this context $(8,9)$.

Some rare findings were reported that dyslipidemia arises from SARS. Specifically, patients with SARS were reported to have reduced total cholesterol (TC) levels compared with healthy participants (10). Alterations in lipoprotein levels during COVID-19 infection were also reported (11-15).

Lipid profiles of patients with COVID-19 and their possible relation with disease severity were retrospectively investigated in our study.

\section{METHODS}

\section{Study Design and Cohort}

A total of 1,509 adult patients with COVID-19 pneumonia diagnosed using the polymerase chain reaction technique and radiologic involvement of computed tomography (CT) scan and admitted to University of Health Sciences Turkey, Bakirköy Dr. Sadi Konuk Training and Research Hospital in Istanbul, level-3 pandemic, from September 01, 2020, to December 31, 2020, were retrospectively observed. The hospital electronic database was screened and patients without clinical or laboratory data or with pneumonia arising from other causes were excluded from the study. Other criteria for exclusion, to reduce the confounding effects, includes the existence of dyslipidemia, use of lipid-lowering therapy, end-stage renal failure, chronic dialysis, nephrotic syndrome, obesity, cholestatic liver disease, chronic use of corticosteroids, immunosuppressive conditions, human immunodeficiency virus (HIV) infection, hypothyroidism, diabetes mellitus, chronic alcoholism, terminal conditions due to cancer, serum albumin level measurement of $<3 \mathrm{~g} / \mathrm{dL}$, and pregnancy or breastfeeding, as well as chemotherapy for cancer treatment.

After the exclusion, 817 patients were enrolled, all of whom were over 18 years old and none was taken to the intensive care unit (ICU). Demographic data, comorbidities, COVID-19-related examinations, respiratory rate, oxygen saturation by pulse oximetry $\left(\mathrm{SpO}_{2}\right)$, and mean oxygen requirement during hospitalization were recorded. Our hospital has accredited laboratories standardized for internal and external quality assurance measures to monitor the precision and accuracy of the performed tests. In all cases, blood samples of fasting were obtained from the peripheral vein within 24 hours of hospitalization. Data were categorized as moderate or severe according to the severity classification of the "Chinese Guidelines for Diagnosis and Treatment of Novel Coronavirus Pneumonia (Trial Version 7)" (16). Patients with moderate COVID-19 had a fever ( $>37.3$ ${ }^{\circ} \mathrm{C}$ ) and respiratory symptoms identified with radiological findings for pneumonia. COVID-19 cases were considered severe with any of the following criteria: "(1) respiratory distress ( $\geq 30$ breaths $/ \mathrm{min}$ ), (2) oxygen saturation of $\leq 93 \%$ at rest, (3) arterial partial pressure of oxygen/fraction of inspired oxygen of $\leq 300 \mathrm{mmHg}(\mathrm{mmHg}=0.133 \mathrm{kPa})$." All patients were scanned with spiral CT on admission. Radiologist-evaluated CT results were classified into three categories: mild, moderate, and severe involvement (17). All study participants were managed according to the "COVID 19 Treatment Protocol of Turkish Health Ministry" (18). The research was first registered in the data of the "Turkish Health Ministry Scientific Research Committee" and then reviewed and approved by the "Local Ethics Committee."

\section{Serum Lipids Measurement}

The dataset consisting of TC, high-density lipoprotein cholesterol (HDL-C)-, and LDL-C were analyzed using the modular dual-phase extraction system "(COBAS-C 501, Roche Diagnostics, Basel, Switzerland)."

\section{Statistical Analysis}

Mean \pm standard deviation values were estimated as descriptive statistics. Deviations from normality were 
assessed using the median and percentage values in the distributions. The Student's t-test was used for continuous variables with normal distributions. Categorical data were analyzed using the chi-square test. Continuous variables having abnormal distribution were evaluated by the Mann-Whitney $U$ test. A $p$-value of $<0.05$ was accepted as statistically significant. Commercially available "Statistical Package for the Social Sciences software v.21 (Statistical Package for the Social Sciences Inc., Chicago, IL, USA)" was used for all the statistical analyses.

\section{RESULTS}

A total of 817 patients with COVID-19 pneumonia participated in this study, wherein 347 were moderate and 470 were severe. Baseline parameters and comorbidities showed no difference in sex. Patients with severe conditions were older than those with moderate ones. Hypertension and heart failure were more frequent $(p=0.003, p<0.001$, respectively) in patients in severe condition than those in moderate condition. $\mathrm{SpO}_{2^{\prime}}$ in baseline and under oxygen support, was lower in severe than in the moderate group. The respiratory rate was higher in the severe group (Table 1). Lymphopenia was lower, whereas neutrophil and platelet counts were higher in the severe than in the moderate group. Glucose, urea, transaminases (alanine aminotransferase and aspartate transaminase), magnesium, and potassium levels were also higher in the severe than in the moderate group. In addition, patients in severe conditions were linked with stronger inflammatory responses, which yielded poor prognostic laboratory findings, such as lactate dehydrogenase, C-reactive protein, troponin I, D-dimer, fibrinogen, and ferritin. Albumin and calcium were lower in patients with severe conditions; however, no difference was found in the procalcitonin between groups. CT revealed a severe involvement in the severe than the moderate group. Thyroid-stimulating hormone and free triiodothyronine values were lower in the severe than in the moderate group, within the reference range. No difference was found in the free thyroxine value between groups. The hospitalization duration was higher in the severe than in the moderate group. TC and LDL-C levels were lower in the severe group than in the moderate group ( $p=0.02, p=0.03$, respectively). A total of 48 patients who died from respiratory failure were all from the severe group. The mortality rate was $10.2 \%$ in the severe group (Table 2). TC and LDL-C have a negative correlation with the hospitalization duration ( $r=-0.163$, $p=0.02 ; r=-0.154, p=0.03$, respectively) (Figure 1, 2).

\section{DISCUSSION}

Lipid profiles of patients hospitalized with COVID-19 pneumonia were retrospectively analyzed based on the clinical laboratory reports of lipid measurements on a large patient population.

Previous studies showed that patients with communityacquired pneumonia had a higher risk of death with reduced LDL-C levels (19). Thus, the risk of sepsis for patients who are hospitalized also increased $(20,21)$. One particular study showed that reduced levels of LDL-C were followed by a higher likelihood of future sepsis, which implied a direct influence of LDL-C on sepsis risk (22).

Table 1. Evaluation of baseline characteristics and comorbidities for patients with moderate and severe conditions

\begin{tabular}{|c|c|c|c|}
\hline & Moderate $(n=347)$ & Severe $(n=470)$ & $\mathrm{p}$ \\
\hline Age, years & $53.89 \pm 16.34$ & $59.38 \pm 14.84$ & $<0.001$ \\
\hline Female, n (\%) & $140(40.34 \%)$ & 169 (35.95\%) & NS \\
\hline Respiratory rate, per minute & $16.39 \pm 2.52$ & $23.5 \pm 4.37$ & $<0.001$ \\
\hline $\mathrm{SpO}_{2}{ }^{1}$ & $95.13 \pm 1.47$ & $93.91 \pm 2.1$ & $<0.001$ \\
\hline Body temperature, oC & $36.93 \pm 0.68$ & $37 \pm 0.74$ & NS \\
\hline Heart rate, per minute & $82.34 \pm 13.54$ & $83.05 \pm 15.39$ & NS \\
\hline Systolic blood pressure, $\mathrm{mmHg}$ & $123.63 \pm 17.87$ & $124.69 \pm 16.8$ & NS \\
\hline Diastolic blood pressure, $\mathrm{mmHg}$ & $70.25 \pm 10.18$ & $70.29 \pm 10.48$ & NS \\
\hline Arterial hypertension on treatment & $90(25.9 \%)$ & $159(33.8 \%)$ & 0.03 \\
\hline Heart failure & $6(1.7 \%)$ & $15(3.2 \%)$ & $<0.001$ \\
\hline COPD 1 กा & $10(2.9 \%)$ & $20(4.2 \%)$ & NS \\
\hline Asthma bronchiale & $27(7.8 \%)$ & $43(9.1 \%)$ & NS \\
\hline
\end{tabular}

"SPO $:$ : Median; under oxygen support, " $" \mathrm{COPD}$ : Chronic obstructive pulmonary disease 
Table 2. Laboratory test evaluation, CT results, and mortality of patients with moderate and severe conditions

\begin{tabular}{|c|c|c|c|}
\hline Characteristics count & Moderate $(n=347)$ & Severe $(n=470)$ & $p$ \\
\hline Neutrophil, cells/mL & $4.24 \pm 2.34$ & $6.05 \pm 2.93$ & $<0.001$ \\
\hline Lymphocytes, cells/mL & $1.34 \pm 0.6$ & $1.06 \pm 0.51$ & $<0.001$ \\
\hline Platelets, cells $/ \mathrm{mL}$ & $237.31 \pm 96.19$ & $251.7 \pm 112.57$ & 0.05 \\
\hline Hematocrit, \% & $38.07 \pm 4.55$ & $38.25 \pm 4.39$ & NS \\
\hline Glucose, mg/dL & $121.66 \pm 34.45$ & $134.8 \pm 48.32$ & $<0.001$ \\
\hline Urea, mg/dL & $30.5 \pm 13.65$ & $37.88 \pm 18$ & $<0.001$ \\
\hline Creatinine, mg/dL & $0.79 \pm 0.24$ & $0.84 \pm 0.55$ & NS \\
\hline$A L T, U / L$ & $39.28 \pm 32.7$ & $51.17 \pm 45.74$ & $<0.001$ \\
\hline AST, U/L & $39.04 \pm 24.49$ & $49.33 \pm 34.05$ & $<0.001$ \\
\hline Lactate dehydrogenase, U/L & $298.99 \pm 103.21$ & $415.06 \pm 180.9$ & $<0.001$ \\
\hline Potassium, mEq/L & $4.15 \pm 0.42$ & $4.21 \pm 0.51$ & 0.05 \\
\hline Sodium, mEq/L & $138.05 \pm 3.49$ & $137.36 \pm 3.71$ & 0.007 \\
\hline Magnesium, mg/dL & $2.05 \pm 0.24$ & $2.09 \pm 0.28$ & 0.04 \\
\hline Calcium, mg/dL & $8.87 \pm 0.57$ & $8.59 \pm 0.55$ & $<0.001$ \\
\hline C-reactive protein, mg/L & $71.04 \pm 62.95$ & $121.66 \pm 80.72$ & $<0.001$ \\
\hline Procalcitonin, ng/mL & $0.2 \pm 0.81$ & $0.43 \pm 3.18$ & NS \\
\hline Ferritin, mcg/L & $377.09 \pm 399.98$ & $668.43 \pm 664.67$ & $<0.001$ \\
\hline D-dimer, mcg FEU/mL & $0.63 \pm 1.05$ & $0.96 \pm 1.23$ & $<0.001$ \\
\hline Fibrinogen, mg/dL & $477.38 \pm 122.24$ & $531.47 \pm 139.97$ & $<0.001$ \\
\hline INR & $1.05 \pm 0.2$ & $1.07 \pm 0.18$ & NS \\
\hline Troponin I, ng/mL & $7 \pm 17.88$ & $21.66 \pm 73.38$ & $<0.001$ \\
\hline Albumin, g/dL & $38 \pm 5.22$ & $34.53 \pm 4.82$ & $<0.001$ \\
\hline Free T3 $(\mathrm{pg} / \mathrm{mL})$ & $2.12 \pm 0.21$ & $2.78 \pm 0.57$ & $<0.001$ \\
\hline Free T4 (ng/dL) & $1.07 \pm 0.23$ & $1.09 \pm 0.37$ & NS \\
\hline $\mathrm{TSH}(\mu \mathrm{IU} / \mathrm{mL})$ & $1.03 \pm 2.28$ & $1.53 \pm 2.46$ & $<0.001$ \\
\hline $\mathrm{TC}(\mathrm{mg} / \mathrm{dL})$ & $159.59 \pm 42.57$ & $150.97 \pm 42.99$ & 0.02 \\
\hline Triglyceride & $145.83 \pm 75.65$ & $144.22 \pm 77.3$ & NS \\
\hline $\mathrm{HDL}-\mathrm{C}(\mathrm{mg} / \mathrm{dL})$ & $33.97 \pm 9.84$ & $33.25 \pm 11.59$ & NS \\
\hline LDL-C (mg/dL) & $96.36 \pm 34.37$ & $89.72 \pm 35.1$ & 0.03 \\
\hline $\mathrm{CT}$ results $(\mathrm{n}, \%)$ & & & $<0.001$ \\
\hline Mild involvement & $126(36.3 \%)$ & $42(8.9 \%)$ & \\
\hline Moderate involvement & $187(53.9 \%)$ & $212(45.1 \%)$ & \\
\hline Severe involvement & $34(9.8 \%)$ & $216(46 \%)$ & \\
\hline Mortality & 0 & $48(10.2 \%)$ & $<0.001$ \\
\hline Duration of hospitalization, day & $7.95 \pm 3.59$ & $12.84 \pm 6.98$ & $<0.001$ \\
\hline
\end{tabular}

Contrarily, altered lipid profiles in patients arise from the inflammation due to viral infection. For instance, patients with HIV have reduced HDL-C and increased LDL-C levels $(23,24)$. Patients with dengue fever disease have reduced LDL-C serum (25), and patients with cirrhotic hepatitis $B$ also have reduced HDL-C and LDL-C levels (26).
Lipid metabolism changes 12 years after recovery in patients infected with SARS (27), thus dyslipidemia is possible to develop in patients with COVID-19-related diseases. However, several published investigations in the literature that examine the cholesterol levels with COVID-19 were reported. 


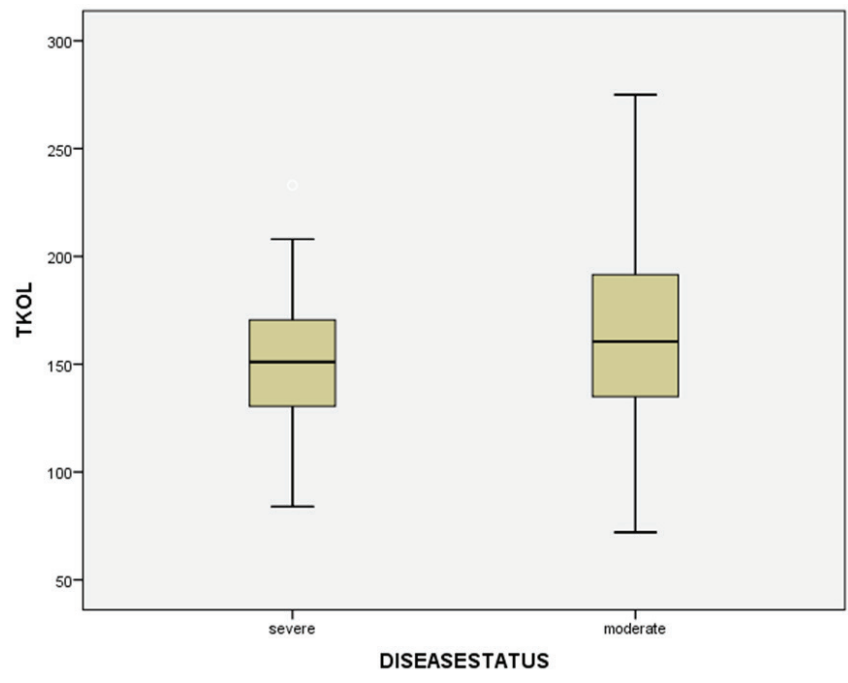

Figure 1: Patients in severe condition show significantly lower TC levels than those in moderate conditions (150.97 \pm 42.99 vs. $159.59 \pm 42.57 \mathrm{mg} / \mathrm{dL}, \mathrm{p}=0.02$ )

TC: Total cholesterol

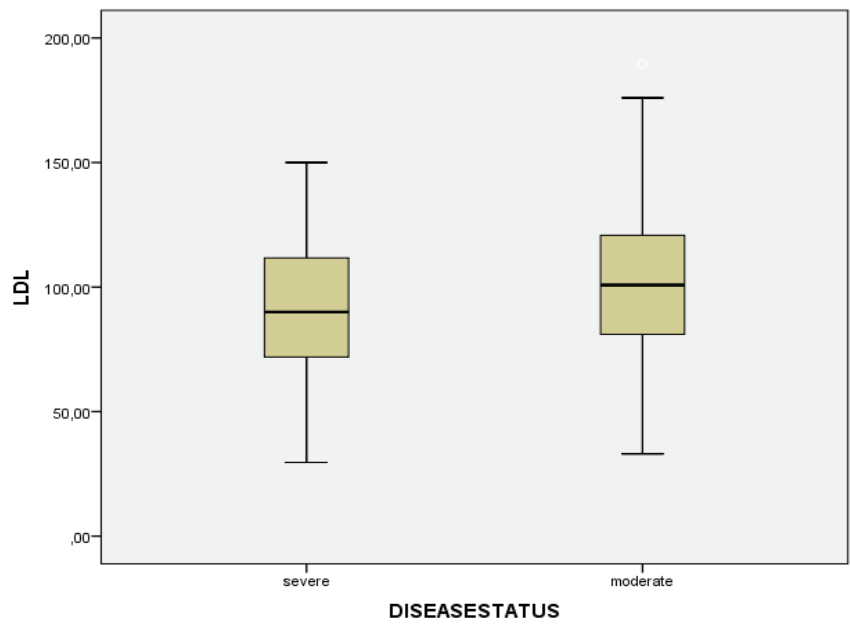

Figure 2. Patients in severe condition show a significantly lower LDL-C level than those in moderate condition (89.72 \pm 35.1 vs. $96.36 \pm 34.37 \mathrm{mg} / \mathrm{dL}, \mathrm{p}=0.03$ )

LDL: Low-density lipoprotein

Generally, published studies reported a reduced level of TC, triglyceride, HDL-C, and LDL-C (11). The severity level in both hypolipidemia and COVID-19 showed a positive correlation (12). In addition, severe consequences emerge more likely in reduced levels of HDL-C in COVID-19 (13). Contrarily, ApoCOVID study showed that HDL-C and LDL-C concentrations upon ICU admission are low in patients with severe COVID-19 pneumonia but are not associated with poor outcomes. However, low lipoprotein concentrations in the case of bacterial superinfection during ICU hospitalization are associated with mortality, which reinforces the potential role of these particles during bacterial sepsis (14). Another recent study demonstrated that LDL-C levels declined perpetually until death in patients hospitalized for COVID-19, though the cohort had a small sample size, which makes one think that LDL-C could potentially predict the disease progress and poor prognosis (15).

Various plausible mechanisms are responsible for dyslipidemia. COVID-19 gave possible harm to liver functions thereby reducing the LDL-C biosynthesis. An acute severe inflammation triggered by COVID-19 changes lipid metabolism or vascular permeability, which in turn leads to the entrance of cholesterol molecules into the alveoli forming exudate and causing a deficit in the plasma LDL-C and cholesterol (28). Another possibility is that the COVID19-activated sterol regulatory element-binding protein-2 disturbs the cholesterol biosynthesis, which usually ends up with a cytokine storm (29).

As lipopolysaccharide creates a reaction with systemic viral infection and/or entrance of a toxic substance, the cholesterol counters the emerging toxic disturbance under selective interaction.

Moreover, LDL-C levels are assumed to be linked to the interplay between dyslipidemia and vasculopathy during a pathological process in patients with COVID-19 (30).

Our results showed that reduced levels of TC and LDL-C were linked with the severity of patients hospitalized with COVID-19 pneumonia. Reduced concentrations of TC and LDL-C most likely resulted from complicated biological and pathological processes caused by COVID-19. Obtained data suggested a decreased LDL-C concentration in patients with COVID-19 is related to disease severity.

\section{Study Limitations}

Several exclusion criteria were used to reduce the confounding effect; however, our findings, showing a correlation between the inferior LDL-C concentrations and poor outcomes of patients hospitalized with COVID-19 pneumonia, had its limitations. The baseline cholesterol levels before the start of the infection were unavailable, which made the precise emergence of reduced LDL-C concentrations uncertain. In addition, the LDL-C level during the recuperation was unrecorded due to the retrospective nature of our design, which resulted in a more pronounced account of the link between the variability of LDL-C concentrations and COVID-19 outcomes.

\section{CONCLUSION}

The variability of LDL concentrations in the vascular system of patients with COVID-19 indicated a strong relationship with the disease severity. Several researchers already demonstrated the strong link between lipid metabolism and COVID-19 in a way that corroborates our observations. 
Therefore, a foreseeable LDL as a marker for predicting COVID-19 severity is not fortuitous.

\section{ETHICS}

Ethics Committee Approval: The study were approved by the University of Health Sciences Turkey, Bakirköy Dr. Sadi Konuk Training and Research Hospital of Local Ethics Committee (no: 2021/127-2021-06-05 date: 15.03.2021).

Informed Consent: Retrospective study.

\section{Authorship Contributions}

Surgical and Medical Practices: M.B., Concept: M.B., Design: M.B., Data Collection or Processing: M.B., I.K.A., Analysis or Interpretation: M.B., I.K.A., Literature Search: M.B., I.K.A., Writing: M.B.

Conflict of Interest: No conflict of interest was declared by the authors.

Financial Disclosure: The authors declared that this study received no financial support.

\section{REFERENCES}

1. Stadler K, Masignani V, Eickmann M, Becker S, Abrignani S, Klenk $H D$, et al. SARS--beginning to understand a new virus. Nat Rev Microbiol 2003;1:209-18.

2. Mackay IM, Arden KE. MERS coronavirus: diagnostics, epidemiology and transmission. Virol J 2015;12:222.

3. Petrosillo N, Viceconte G, Ergonul O, Ippolito G, Petersen E. COVID-19, SARS and MERS: are they closely related? Clin Microbiol Infect 2020;26:729-34.

4. Zhou $P$, Yang $X L$, Wang $X G$, Hu B, Zhang L, Zhang W, et al. A pneumonia outbreak associated with a new coronavirus of probable bat origin. Nature 2020;579:270-3.

5. Goldstein MR, Poland GA, Graeber CW. Are certain drugs associated with enhanced mortality in COVID-19? QJM 2020;113:509-10.

6. Minetti G. Mevalonate pathway, selenoproteins, redox balance, immune system, Covid-19: Reasoning about connections. Med Hypotheses 2020;144:110128.

7. Meilhac O, Tanaka S, Couret D. High-Density Lipoproteins Are Bug Scavengers. Biomolecules 2020;10:598.

8. Lingwood D, Simons K. Lipid rafts as a membrane-organizing principle. Science 2010;327:46-50

9. Simons K, Ikonen E. Functional rafts in cell membranes. Nature 1997;387:569-72.

10. Song SZ, Liu HY, Shen H, Yuan B, Dong ZN, Jia XW, et al. [Comparison of serum biochemical features between SARS and other viral pneumonias]. Zhongguo Wei Zhong Bing Ji Jiu Yi Xue 2004;16:664-6.

11. Ressaire Q, Dudoignon E, Moreno N, Coutrot M, Dépret F. Low total cholesterol blood level is correlated with pulmonary severity in COVID-19 critical ill patients. Anaesth Crit Care Pain Med 2020;39:733-5.

12. Wei $X$, Zeng W, Su J, Wan H, Yu X, Cao X, et al. Hypolipidemia is associated with the severity of COVID-19. J Clin Lipidol 2020;14:297-304.
13. Wang G, Zhang $Q$, Zhao X, Dong H, Wu C, Wu F, et al. Low highdensity lipoprotein level is correlated with the severity of COVID-19 patients: an observational study. Lipids Health Dis 2020;19:204.

14. Tanaka S, De Tymowski C, Assadi M, Zappella N, Jean-Baptiste $\mathrm{S}$, Robert $\mathrm{T}$, et al. Lipoprotein concentrations over time in the intensive care unit COVID-19 patients: Results from the ApoCOVID study. PLoS One 2020;15:e0239573.

15. Fan J, Wang H, Ye G, Cao X, Xu X, Tan W, et al. Letter to the Editor: Low-density lipoprotein is a potential predictor of poor prognosis in patients with coronavirus disease 2019. Metabolism 2020;107:154243

16. Diagnosis and Treatment Protocol for Novel Coronavirus Pneumonia (Trial Version 7). Chin Med J (Engl) 2020;133:1087-95.

17. Yang R, Li X, Liu H, Zhen Y, Zhang $X$, Xiong $Q$, et al. Chest CT Severity Score: An Imaging Tool for Assessing Severe COVID-19. Radiol Cardiothorac Imaging 2020;2:e200047.

18. Republic of Turkey Ministry of Health. Covid-19 (SARS-CoV-2 Infection) Guide. Available @:covid-19rehberieriskinhastatedavisip df.pdf (saglik.gov.tr), (Accessed 20/07/2020.)

19. Chien YF, Chen CY, Hsu CL, Chen KY, Yu CJ. Decreased serum level of lipoprotein cholesterol is a poor prognostic factor for patients with severe community-acquired pneumonia that required intensive care unit admission. J Crit Care 2015;30:506-10.

20. Shor R, Wainstein J, Oz D, Boaz M, Matas Z, Fux A, et al. Low serum $\mathrm{LDL}$ cholesterol levels and the risk of fever, sepsis, and malignancy. Ann Clin Lab Sci 2007;37:343-8.

21. Lagrost L, Girard C, Grosjean S, Masson D, Deckert V, Gautier T, et al. Low preoperative cholesterol level is a risk factor of sepsis and poor clinical outcome in patients undergoing cardiac surgery with cardiopulmonary bypass. Crit Care Med 2014;42:1065-73.

22. Guirgis FW, Donnelly JP, Dodani S, Howard G, Safford MM, Levitan $E B$, et al. Cholesterol levels and long-term rates of communityacquired sepsis. Crit Care 2016;20:408.

23. Baker J, Ayenew W, Quick H, Hullsiek KH, Tracy R, Henry K, et al. High-density lipoprotein particles and markers of inflammation and thrombotic activity in patients with untreated HIV infection. J Infect Dis 2010;201:285-92.

24. Rose H, Hoy J, Woolley I, Tchoua U, Bukrinsky M, Dart A, et al. HIV infection and high density lipoprotein metabolism. Atherosclerosis 2008;199:79-86.

25. Lima WG, Souza NA, Fernandes SOA, Cardoso VN, Godói IP. Serum lipid profile as a predictor of dengue severity: A systematic review and meta-analysis. Rev Med Virol 2019;29:e2056.

26. Cao WJ, Wang TT, Gao YF, Wang YQ, Bao T, Zou GZ. Serum Lipid Metabolic Derangement is Associated with Disease Progression During Chronic HBV Infection. Clin Lab 2019;65.

27. Wu Q, Zhou L, Sun X, Yan Z, Hu C, Wu J, et al. Altered Lipid Metabolism in Recovered SARS Patients Twelve Years after Infection. Sci Rep 2017;7:9110.

28. Heffner JE, Sahn SA, Brown LK. Multilevel likelihood ratios for identifying exudative pleural effusions( $\left.{ }^{\star}\right)$. Chest 2002;121:1916-20.

29. Lee W, Ahn JH, Park HH, Kim HN, Kim H, Yoo Y, et al. COVID-19activated SREBP2 disturbs cholesterol biosynthesis and leads to cytokine storm. Signal Transduct Target Ther 2020;5:186.

30. Cao X, Yin R, Albrecht H, Fan D, Tan W. Cholesterol: A new game player accelerating vasculopathy caused by SARS-CoV-2? Am J Physiol Endocrinol Metab 2020;319:E197-E202. 